\title{
CROSS PROTECTION BY HEAT AND COLD SHOCK TO LETHAL TEMPERATURES IN CLOSTRIDIUM PERFRINGENS
}

\author{
Santos García; Julio C. Limón; Norma L. Heredia* \\ Laboratorio de Bioquímica y Genética de Microorganismos, Departamento de Microbiología. \\ Facultad de Ciencias Biológicas, Universidad Autónoma de Nuevo León. San Nicolás, Mexico
}

Submitted: November 24, 1999; Returned to authors for corrections: July 17, 2000; Approved: March 07, 2001

\begin{abstract}
A heat shock pre-treatment of Clostridium perfringens provides protection against lethality from subsequent exposure to cold shock and vice versa. Heat shocked cells were more cold tolerant (one log reduction in $65 \mathrm{~min}$ ) than control cells (one log reduction in $34 \mathrm{~min}$ ). On the other hand, cold-shocked cells were more thermotolerant $\left(\mathrm{D}_{55}=17\right.$ $\mathrm{min}$ ) than the control $\left(\mathrm{D}_{55}=6.5 \mathrm{~min}\right)$. The addition of chloramphenicol (an inhibitor of protein synthesis) in the experiments indicates that synthesis of new proteins was necessary for cross protection between both treatments.
\end{abstract}

Key words: Clostridium perfringens, heat shock, cold shock

\section{INTRODUCTION}

Several authors have reported that when organisms are exposed to high sublethal temperatures, they are able to survive higher lethal temperatures $(3,15,19)$. On the other hand, sublethal cold shock enables cells to survive to lower lethal temperatures $(1,5,11,12)$.

C. perfringens is responsible for one of the most common types of human food-borne illness. This is a gram-positive, spore forming, rod-shaped, encapsulated and non motile bacterium. The generally accepted temperature range for growth is between 15 and $50^{\circ} \mathrm{C}(14)$. The most important characteristic of $C$. perfringens relative to food safety is its ability to grow rapidly at elevated temperatures (4). The potential impact of such an ability on food safety is obvious. In our laboratory, we have observed that when cells were exposed to heat shock, they acquired heat tolerance (7).

Recently, several reports have indicated that cross protection between different lethal or adverse treatments can be induced in some microorganisms $(9,10,21,22)$. However, no information is available about protection between heat and cold treatments. Because of the exposure of several foods to low and high temperatures during its preparation and storage, it is important to study the ability of the food-borne pathogen $C$. perfringens to survive extreme temperatures. In this work, we examined the effect of sublethal high and low temperatures on the cold and heat tolerance, respectively, of this bacterium. Furthermore, the role of new protein synthesis on tolerance was determined by the use of chloramphenicol (an inhibitor of protein synthesis) in the experiments.

\section{MATERIALS AND METHODS}

An enterotoxin-positive strain, FD-1041 of C. perfringens was used. It was kindly provided by S. Harmon from the Food and Drug Administration, Washington, D.C. The strain was maintained as a stock spore culture in Cooked Meat medium (Difco, Detroit, MI) at $-20^{\circ} \mathrm{C}$. Active cultures were obtained by transferring two drops of the stock culture into screw capped tubes containing 10 $\mathrm{ml}$ of Fluid Thioglycolate Medium (FTG, Difco), heat-activating $\left(75^{\circ} \mathrm{C} / 15 \mathrm{~min}\right)$ and incubating overnight $(16-18 \mathrm{~h})$ at $37^{\circ} \mathrm{C}(6)$.

From an activated culture, $13 \times 100 \mathrm{~mm}$ tubes containing two $\mathrm{ml}$ of fresh FTG were inoculated (1\% inoculum) and incubated at $43^{\circ} \mathrm{C}$. Caution was taken to inoculate directly on the medium, and avoid contaminating the top internal surface of the tube. When

\footnotetext{
* Corresponding Author. Mailing address: Laboratorio de Bioquímica y Genética de Microorganismos, Departamento de Microbiología. Facultad de Ciencias Biológicas, Universidad Autónoma de Nuevo León. Apto. Postal 124-F. San Nicolás, Mexico. Telefax: (+52-8) 3763044. E-mail: nheredia@ccr.dsi.uanl.mx.
} 
cells reached mid-log phase $\left(\mathrm{A}_{600}=0.6-0.7\right)$, the culture was treated one of two ways. To determine the induction of cold tolerance as a result of a previous heat shock, some cultures were immersed in a water bath at $50^{\circ} \mathrm{C}$ for $30 \mathrm{~min}$. At the beginning of this treatment, chloramphenicol (200 $\mu \mathrm{g} / \mathrm{ml}$ final concentration) was added to some cultures (18). Control cultures were not heated. Following the $30 \mathrm{~min}$, all the cultures were immediately submerged in a refrigerated water bath at $10^{\circ} \mathrm{C}$ for one $\mathrm{h}$. Viable cells were enumerated by plate count at 20 min intervals using a medium composed of $1 \%$ yeast extract, $1.5 \%$ Bacto Tryptone and $1.5 \%$ agar (Difco). Pour plates were incubated anaerobically in a mixture of $\mathrm{CO}_{2}$ and $\mathrm{N}_{2}(90: 5)$ at $37^{\circ} \mathrm{C}$. Colonies were counted after $48 \mathrm{~h}$ and the data plotted. Death curves of the different treatments were obtained by the least-squares regression method. The time required to reduce the number of viable cells by one $\log$ ("D" value) was determined from the slope of the linear portion of the death curves (4).

To determine induction of heat tolerance as a result of a previous cold shock, several tubes were immersed in the refrigerated water bath at $15^{\circ} \mathrm{C}$, for $30 \mathrm{~min}$. Chloramphenicol was added to several cultures as described before. Control tubes were not cold shocked. Following the $30 \mathrm{~min}$ treatment, all tubes were immediately submerged in a hot water bath at $55^{\circ} \mathrm{C}$ for $15 \mathrm{~min}$. Viable cells were determined at five min intervals as previously described. " $D$ " values were determined.

Due to innate resistance of $C$. perfringens at 55 or $10^{\circ} \mathrm{C}$, analyses of tolerance at these temperatures were carried out at intervals of 5 or $20 \mathrm{~min}$ respectively. In this case, cells were damaged more rapidly at the higher temperature than the lower. All experiments were done at least in triplicate. The " $\mathrm{t}$ " method was used to determine differences between slopes from death curves (23).

\section{RESULTS AND DISCUSSION}

Our results indicate that a cross protection between both treatments is produced in C. perfringens as a result of temperature stresses. Cells submitted previously to cold shock $\left(15^{\circ} \mathrm{C}\right.$ for 30 min) were significantly $(P<0.05)$ more resistant to $55^{\circ} \mathrm{C}$ when compared to the control (Fig. 1). D values for cold-treated cells were $17 \mathrm{~min}$ as compared to $6.5 \mathrm{~min}$ for control cells (Table 1). These results indicated that cold shocked cells were 2.6 times more heat tolerant than the control. No significant difference in heat tolerance was observed between control cells and those receiving chloramphenicol.

Cells previously submitted to a heat shock induced by increasing the temperature from 43 to $50^{\circ} \mathrm{C}$, were almost two fold more resistant $(P<0.05)$ to cold temperature $\left(10^{\circ} \mathrm{C}\right)$ than those of the control (Fig. 2). In this case, the time required to reduce the population one-log was 65 min for heat-treated cells, while the same reduction was achieved in $34 \mathrm{~min}$ in the control (Table 1). Also, no significant difference in cold tolerance was observed between control cells that were treated or untreated with chloramphenicol and shocked cells treated with chloramphenicol. Viable cell counts of cultures treated with chloramphenicol increased after cells were transferred to a fresh antibiotic-free medium (data not shown).

Some authors have reported that exposure to a stress condition can enable microorganisms to become resistant to other kinds of

Table 1. Decimal reduction times at high and low temperatures of previously cold and heat shocked cells respectively of $C$. perfringens.

\begin{tabular}{lcc}
\hline Treatment & D value (min) & \\
& $(P=0.05)$ & \\
\hline & $55^{\circ} \mathrm{C}$ & $10^{\circ} \mathrm{C}$ \\
Control & $6.5 \pm 0.5$ & $34 \pm 4$ \\
Control + Chloramphenicol & $5.2 \pm 0.2$ & $37 \pm 3.5$ \\
Shocked cells* & $17 \pm 1^{\mathrm{A}}$ & $65 \pm 2.5$ \\
Shocked cells + Chloramphenicol & $6.1 \pm 0.3^{\mathrm{A}}$ & $33 \pm 2$ \\
\hline
\end{tabular}

*: cells were previously shocked at $\left(15^{\circ} \mathrm{C} \text { for } 30 \mathrm{~min}\right)^{\mathrm{A}}$ or $\left(50^{\circ} \mathrm{C}\right.$ for $30 \mathrm{~min}$ ).

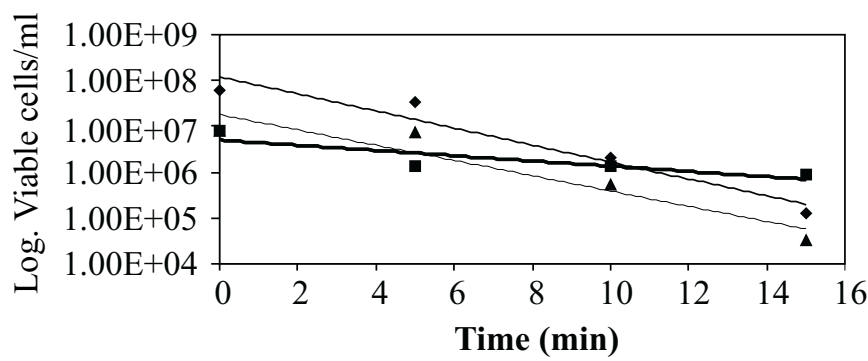

- Control $~ \bullet$ Cold Shocked $\left(15^{\circ} \mathrm{C}\right.$ for $\left.30 \mathrm{~min}\right) \Delta$ Cold shocked + chloram

Figure 1. Inactivation of $C$. perfringens cells at $55^{\circ} \mathrm{C}$. Cells were previously cold shocked and in some cases chloramphenicol was added.

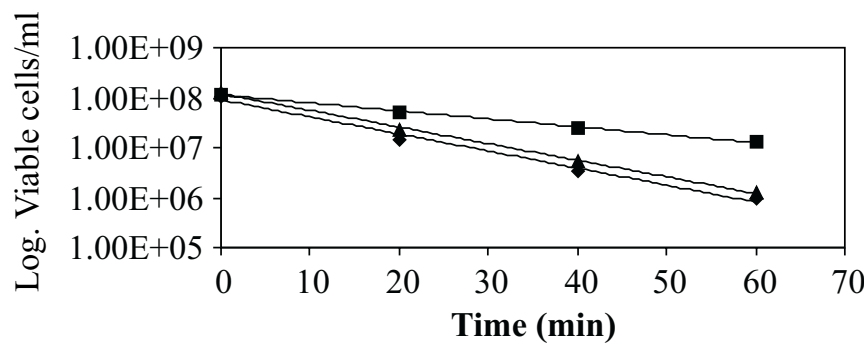

- Control $\mathbf{~ C o l d ~ S h o c k e d ~}\left(50^{\circ} \mathrm{C}\right.$ for $\left.30 \mathrm{~min}\right) \wedge$ Cold shocked + chloram

Figure 2. Inactivation of $C$. perfringens cells at $10^{\circ} \mathrm{C}$. Cells were previously heat shocked nd in some cases chloramphenicol was added. 
stresses. In some microorganisms, heat shock induces protection against subsequent exposure to salt (21) and hydrostatic pressure (11) stresses, and increases superoxide dismutase activity (2). On the other hand, cold shock induces protection against acrylic acid and copper ions (22). Although in Escherichia coli, a strong cold shock represses synthesis of heat shock proteins (11), in other microorganisms several proteins are induced by both heat and cold shock $(8,13,16,20)$. Recently it was reported that $E$. coli exposed to heat, cold, oxidative and tetracycline-induced stresses secreted exometabolites that protected the cells against the same or other stresses (17). The present study demonstrated that heat shock induced protection against cold shock and vice versa in $C$. perfringens. The presence of chloramphenicol (an inhibitor of protein synthesis) in the experiments indicates that synthesis of new proteins during the first shock is necessary for cross protection between both treatments. Studies are under way to determine the proteins involved in both stresses in $C$. perfringens and to determine if this cross protection is also exhibited by $C$. perfringens in foods and contribute to foodborne disease outbreaks.

Therefore, protection against lethal hot or cold temperatures was achieved by $C$. perfringens as a result of a previous exposure to the counterpart sublethal temperature. The effect of temperature tolerance on the biomedical aspects of food safety may be important, because of the widespread application of thermal processing or refrigeration storage for the control of pathogenic microorganisms associated with food.

\section{ACKNOWLEDGMENTS}

This work was supported by Consejo Nacional de Ciencia y Tecnología de Mexico (CONACYT). The authors thank Dr. Ronald G. Labbé for his valuable comments and criticism.

\section{RESUMO}

\section{Proteção cruzada por choque pelo calor e frio à temperaturas letais em Clostridium perfringens}

Um pré-tratamento com choque térmico em Clostridium perfringens resulta em proteção contra letalidade a uma posterior exposição a choque pelo frio, e vice-versa. Células submetidas a choque pelo calor foram mais tolerantes ao frio (redução de um log em 65 min) do que células controle (redução de um log em 34 min). Por outro lado, células submetidas à choque pelo frio foram mais termotolerantes $\left(D_{55}=17 \mathrm{~min}\right)$ do que os controles $\left(D_{55}=6,5\right.$ min). A adição de cloranfenicol (um inibidor de síntese protéica) nos experimentos indica que síntese de novas proteínas era necessária para a proteção cruzada pelos dois tratamentos.

Palavras-chave: Clostridium perfringens, choque térmico, choque pelo frio

\section{REFERENCES}

1. Berg, G.R.; Inniss, W.E.; Heikkila, J.J. Stress proteins and thermotolerance in psychrotrophic yeasts from arctic environments. Can. J. Microbiol., 33:383-389, 1987

2. Begonia, G.B.; Salin, M.L. Elevation of superoxide dismutase in Halobacterium halobium by heat shock. J. Bacteriol., 173:55825584, 1991.

3. Blankenship, L.C.; Craven, S.E.; Loffler, R.G.; Custer, C. Growth of Clostridium perfringens in cooked chili during cooling. Appl. Environ. Microbiol., 54:1104-1107, 1988.

4. García-Alvarado, J.S.; Labbé, R.G.; Rodríguez, M.A. Sporulation and enterotoxin production of Clostridium perfringens type A at 37 and $43^{\circ}$ C. Appl. Environ. Microbiol., 58:1411-1414, 1992.

5. Goldstein, J.; Pollit, N.S.; Inouye, M. Major cold shock protein of Escherichia coli. Proc. Natl. Acad. Sci. USA, 87:283-287, 1990.

6. Heredia, N.L.; Labbe, R.G.; Rodriguez, M.A.; Garcia-Alvarado, J.S. Growth, sporulation and enterotoxin production by Clostridium perfringens type $\mathrm{A}$ in the presence of bile salts. FEMS Microbiol. Lett., 84:15-22, 1991.

7. Heredia, N.L.; García, G. A.; Luévanos, R.; García-Alvarado, J. S.; Labbé, R.G. Elevation of the heat resistance of vegetative cells and spores of Clostridium perfringens by sublethal heat shock. J. Food Prot., 60:998-1000, 1997.

8. Heredia, N.L.; García-Alvarado, J.S.; Labbé, R.G. Alteration in sporulation, enterotoxin production and protein synthesis by Clostridium perfringens type A following heat shock. J. Food Prot., 61:1143-1149, 1998

9. Humprey, T.J.; Richardson, N.P.; Gawler, A.H.L.; Allen, M.J. Heat resistance of Salmonella enteritidis PT4: the influence of prior exposure to alkaline conditions. Lett. Appl. Microbiol., 12:258-260, 1991.

10. Iwahashi, H.S.; Kaul, C.; Obuchi, K.; Komatsu, Y. Induction of barotolerance by heat shock treatment in yeast. FEMS Microbiol. Lett., 80:325-328, 1991.

11. Jones, P.G.; Inouye, M. The cold-shock response: a hot topic. Mol. Microbiol., 11:811-818, 1994.

12. Jones, P.G.; VanBolegen, R.A.; Neidherdt, F.C. Induction of proteins in response to low temperature in Escherichia coli. J. Bacteriol., 169:2092-2095, 1987.

13. Kucerová, H.; Chaloupka, J. Intracellular serine proteinase behaves as a heat-stress protein in nongrowing but as a cold-stress protein in growing populations of Bacillus megaterium. Curr. Microbiol., 31:39-43, 1995.

14. Labbé, R.G. Clostridium perfringens. In: Doyle, M.P. (ed) Foodborne Bacterial Pathogens. Marcel Dekker, New York, 1989, p.191-234.

15. Mackey, B.M.; Derrick, C.M. The effect of prior heat shock on the thermoresistance of Salmonella thompson in foods. Lett. Appl. Microbiol., 5:115-118, 1987.

16. Maniak, M.; Nellen, W. A developmentally regulated membrane protein gene in Dictyostelium discoideum is also induced by heat shock and cold shock. Mol. Cell Biol., 8:153-159, 1988.

17. Nikolaev, Y.A. Involvement of exometabolites in stress adaptation of Escherichia coli. Microbiology (Translated from Mikrobiologiya), 66:38-41, 1997.

18. O'Brien, L.M.; Gordon, S.V.; Roberts, I.S.; Andrew, P.W. Response of Mycobacterium smegmatis to acid stress. FEMS Microbiol. Lett., 139:11-17, 1996.

19. Shah, D.B.; Bradshaw, J.G.; Peeler, J.T. Thermal resistance of eggassociated epidemic strains of Salmonella enteritidis. J. Food Sci., 56:391-393, 1991 .

20. Villarreal, L.; Heredia, N.L.; García, S. Changes in protein synthesis and acid tolerance of Clostridium perfringens type A as a result of an acid shock. Internatl. Microbiol., 3:113-116, 2000.

21. Völker, U.; Mach, H.; Schmid, R.; Hecker, M. Stress proteins and cross-protection by heat shock and salt stress in Bacillus subtilis. J. Gen. Microbiol., 138:2125-2135, 1992.

22. Whiting, G.C.; Rowbury, R.J. Increased resistance of Escherichia coli to acrylic acid and to copper ions after cold-shock. Lett. Appl. Microbiol., 20:240-242, 1995.

23. Zar, J.H. Biostatistical Analysis. Prentice Hall, New Jersey, 1996, 662p. 